\title{
LÁNG ÉVA
}

\section{A TÁNCTANÍTÁS MÓDSZERTANI KERETEI}

\author{
Eszterházy Károly Egyetem, Sporttudományi Intézet \\ lang2.eva@uni-eszterhazy.hu
}

\begin{abstract}
Absztrakt
Táncot oktatni ugyancsak felemelő érzés. Elűzi a stresszt, kiszakít a mindennapok egyhangúságából vagy az állandó rohanásból. Egyre több iskola fedezi fel a sport mellett a tánc igazán jótékony hatásait. Célként jelenik meg, hogy a táncokat már korábban elsajátító pedagógusjelölteknek olyan módszertani segítséget nyújtani, amely a táncoktatásban az oktatás és a tanulás folyamatára, illetve célok és feladatok elérését támogató módszerekre épül. Tisztában kell azzal lenni, hogy egy egyszerű táncfoglalkozással milyen sokrétű kompetenciák fejleszthetőek, legyen szó esztétikai, erkölcsi nevelésről vagy éppen értékek közvetítéséről. Az oktatói tevékenységnél elvárt, hogy a képzők célirányosan tudják megválasztani a megfelelő eszközöket annak érdekében, hogy képesek legyenek alkalmazni a módszerek egymásutániságát az ismertközléstől a gyakoroltatáson és hibajavításon át egészen az ellenőrzésig. Tudják a célokat részcélokra bontani, ismerjék a mozgáskészség kialakításának szakaszait, és tudatosan tudják alkalmazni azokat a munkájuk során. Legyenek tekintettel a tanulók életkorára és képességeire, a tanítványaik előképzettségeire, a csoport összetételére, képesek legyenek a differenciálásra. Emellett szó esik a tánc tanításának külső és belső feltételeiről, a zenét biztosító technikai eszközökről, a tanár kompetenciáiról és attitűdjéről. Fontos, hogy nem elég felelőségteljesen megtanulni tanítani. Táncot megszerettetve oktatni igazán az képes, aki maga is szereti az átadandó zenés-táncos mozgásformákat.
\end{abstract}

Kulcsszavak: táncoktatás, eszköztár, tanári kompetenciák, mozgáskészség kialakítása 


\section{Bevezetés}

„Furcsán viselkedik néha az ember. Zenét hall, s erre elkezd mozogni, hajladozni, lépkedni. Nem végez semmiféle hasznos munkát, nem megy sehová. Mindez nem jelenthet fáradságot, kínos kötelességet számára, hiszen önként teszi, sőt még mosolyog is hozzá. Boldognak látszik, ami oly ritka az ember életében. Mit tesz hát? Táncol. Táncolni jó, táncolni mámorító. A tánc felüdít, szórakoztat, bizonyos szempontból pihentet mind szellemileg, mind testileg. S ez a remek dolog ráadásul nem függ sem társadalmi, sem vagyoni helyzettől, még életkortól se nagyon. A fiataloknak annyi testmozgást biztosít, amennyit igényelnek, a középkorúaknak sem megerőltető."

Ez az idézet Antal Imrétől származik, aki Alex Moore Társastánc címú könyvében írta meg gondolatait az előszóban. Teljes mértékben egyetértek ezzel, mert én is átéreztem a tánc szépségét múfajtól függetlenül. Már az egy-két éves gyermekeknél tapasztalható, mennyire velünk született a tánc képessége, szeretete. Halljon a kicsi bármilyen stílusú dallamot, rögtön figyel, és valamilyen módon reagál rá. Táncol, rugózik, emelgeti lábát, mozgatja csípőjét, és közben mosolyog. Ennél jobb bizonyíték nem is kell arra, hogy az ember létszükségletei közé tartozik a tánc is, legyen szó ép vagy sérült embertársainkról. Ezzel a mozgásformával megismerkedve nemcsak motoros és esztétikai, hanem a lelki fejlődésen túl társas kapcsolatokon keresztül biztosítjuk számukra a kulturált szórakozás élményét.

\section{A tánc pedagógiai haszna}

A tánc formálja a személyiséget, fejleszti a ritmusérzéket, a pozitív élmények olyan emberi, magatartásbeli attitüdöket alakítanak ki, mellyel nemcsak a múvészetek eredményes szereplőivé válhatnak, hanem a társadalmi élethez szükséges erkölcsi kompetenciáik is fejlődnek, mint például a fegyelmezettség, határozottság, közösségi magatartás, aktivitás, csapatban gondolkodás, empátia, önismeretet, együttmúködési készség, akarat, segítőkészség, szolidaritás, önuralom. A szabadidő hasznos eltöltéséhez kiváló fejlesztő lehetőség a tánc.

\section{A táncoktatásának célja és feladatai}

Cél, hogy a tánc az egészséges testi, lelki és esztétikai fejlődésen túl

1. elégítse ki a résztvevők mozgásszükségleteit, miközben az edzettségi szintjük, teherbíró képességük fokozódik, fejlődik a fizikai és mentális állóképességük egy pozitív hangulatú időtöltésen keresztül, akár szabadidős tevékenységként végzik, akár kötelező oktatásban részesülnek, 
2. alakítson ki értékes emberi tulajdonságokkal és jellemvonásokkal rendelkező egyént,

3. fejlessze az esztétikai érzéket, tegyen szert a résztvevő magas mozgásmüveltségre,

4. segítsen kialakítani csoportos játékhoz szükséges képességeket, rögtönözni tudást, problémamegoldó, ismeretszerzési, tanulási kompetenciákat,

5. növelje a tanuló megismerő-, befogadóképességét, mely által nyitottá válik a hagyományaink, a kultúránk iránt, érdeklődését felkelthetik a társművészetek,

6. fejlessze az ízlést, a kritikai érzéket, a mozgáskultúrát, a mozgáskoordinációt, a ritmusérzéket, a hallást, a környezettel való harmonikus, konstruktív kapcsolathoz szükséges képességeket, készségeket,

7. fejlessze a tanuló azon képességét, hogy el tudja magát helyezni a térben, melyben képes lesz mozogni, kifejezni magát nonverbális kommunikációval is.

A tánc tanításánál az oktatói munka a gyakorlatban valósul meg. A tánc módszertana a tánc oktatásának sajátos problémáival foglalkozik. A nevelési kérdések mások korosztályonként és képességi szintenként. Az oktatás során mozgásokat tanítunk, ezért a mozgásoktatás sajátos tanítás-tanulás problémáit, lehetőségeit és törvényszerüségeit kell vizsgálni.

\section{Esztétikai nevelés}

Az esztétikai nevelés „arra irányul, hogy az egyénben kifejlessze az esztétikai jelenségek felismeréséhez, értelmezéséhez, élvezéséhez és elsajátításához szükséges érzékenységet (...) és személyiségét építő erővé tegye az esztétikai jelenségekben benne rejlő, a felismerés, értelmezés, élvezés és elsajátítás által birtokba vett, magáévá asszimilált emberi-esztétikai tartalmakat" (Poszler, 1980).

Ha kisgyermeket figyelünk, rájövünk arra, hogy a spontán megvalósuló mozgásaik, a zenei lüktetés érzékelése igen mélyen gyökerezik. Megmutatkozik az, hogy hogyan indulnak el a zene világában. Az improvizált mozgásaik komplikáltabb zenei műveletekre képesek, mint a szokásos utánzásból indított tanulás során. A gyermek sokszor teljesen elmerül abban a zenében, amit éppen hall, és teljesen önmagát adja. Számára a mozgás létszükséglet. A táncban az általános esztétikai törvényszerűségek alapján kell foglalkozni a gyerekekkel. Tudatában kell lennünk annak, hogy az első pillanattól kezdve a gyermek teste formálódik, és ezzel egyidejűleg a lelki finomodás is elkezdődik. A képzés alatt egyidejüleg fejlődik motorikus és akusztikus irányban is.

"Az érzelem, akarat és értelem hullámhosszain finomítjuk a technikai szintet, a látásmódot és a hallás képességét. Így közelítheti meg a tanár célkitűzését: Harmonikus tartás és mozgás- harmonikus gyermek" (Berczik, 1993). 


\section{Az oktatás folyamata a táncoktatásban}

Az oktatási és nevelési folyamat a tánctanár irányításával történik, amely során a tanulók jártasságokat, készségeket, képességeket sajátítanak el. A folyamat alatt különböző hatások érik őket, melynek eredményeként fejlődik a karakterük, személyiségük.

Az oktatás folyamatában a tanár feladata a tanítás, a tanulóké a tanulás, mindezt természetesen szoros együttműködés keretében. A tanár által megtanított anyag erőfeszítéseket igényel a tanulóktól, amely fejleszti a tanítvány tudásán és képességein túl a jellemét, és ami által a pedagógus a nevelés kérdését oldja meg. A tanulás alatt a tanulóknak nehézségekkel kell szembenézniük, aminek a leküzdéséhez önfegyelem kell, ami pedig az önneveléshez járul hozzá. Így fejlődik a személyiségük is.

Az oktatás folyamatát meg kell tervezni, mely tágabb értelemben lehet a tanfolyam időtartama, iskolában egy tanítási egység vagy év (esetleg évek sorozata), versenyzőknél versenyévad stb., szűkebb értelemben az adott anyagrész feldolgozása a tanórákon.

Az oktatás folyamatán belül létezik egy 2 komplex fázisból álló makro-struktúra, mely elsősorban ismeretszerzés-alkalmazás formájában jelenik meg. Létezik egy mikro-struktúra is, amely a makro-struktúra fázisainak didaktikai folyamatokra való bontását jelenti (Báthory, 1981).

Az oktatás folyamatát általánosságban az alábbi mozzanatok jellemzik (Rátkai, 2000):

1. A tanulók megismertetése a konkrét tényekkel (tánc: történet, karakter, stílus)

2. A megismert tények elemzése

3. Fogalom és szabályalkotás (absztrakció és általánosítás)

4. Rögzítés, megszilárdítás

5. Gyakorlati alkalmazás

6. Ellenőrzés

A makrostruktúra 3 fö részre osztható, ezen belül vizsgálhatjuk a mikrostruktúrát.

1. Ismeretek
a, bemutatás
b, magyarázat
c, elsődleges gyakorlás, a végrehajtás megkísérlése
d, lényeges, kulcsmozzanat kiemelése
e, szabályalkotás 
2 Rögzítés
a, első gyakorlás sok hibával
b, hibajavítás, a durva hibák kiküszöbölése
c, második gyakorlás
d, hibajavítás, a gyakorlás finomítása
e, szükség szerint újabb bemutatás és magyarázat
f, harmadik gyakorlás, a mozgás csiszolása, hatáskiváltás

3 Gyakorlati alkalmazás
a, a tanulás alkalmazása azonos körülmények között
b, a begyakorlott mozgás alkalmazása változó körülmények között
c, a tanult mozgás ellenőrzése, kialakul a készség

\section{A mozgáskészségek kialakításának folyamata}

A készség a tudatos tevékenység automatizált komponense (Nagy, 1967). A készség kialakulása sokszori gyakorláson és alkalmazáson múlik (Bognár, Tóth, Baumgarner, 2003). Ahhoz, hogy ez megvalósuljon, az ismereteknek és a szükséges képességeknek szilárd alapon kell állniuk.

A mozgástanulás komplex folyamata során ki kell alakítani reflexkapcsolatokat, hogy a mozgás készséggé alakuljon, vagyis automatizálódjon (Bognár és mtsai, 2005). A tánc tanításában Knapp (1968) elmélete a legoptimálisabb, amely öt fázisra osztja fel a mozgástanulás folyamatát. Ezek rövid bemutatása következik.

Az 1. szakaszban a mozgásminta kialakulása történik. A tanuló képet alkot az elsajátításra váró feladatról. Kialakul az ún. ideomotoros kapcsolat, amely belső késztetést jelent a tényleges cselekvésre vonatkozóan. Itt történik a mozgásminta kialakulása.

A 2. szakaszban történik az első végrehajtási kísérlet az adott mozgásminta alapján. Ebben a szakaszban az első kísérletek után az idegrendszeri folyamatokat a serkentés jellemzi. Ekkor még sokkal több izom kapcsolódik be, mint amennyire szükség lenne. A mozgás merev és görcsös. Hiányzik a mozgás harmonikus szerkezete, a téri, időbeli és dinamikai eleme.

A 3. szakaszra a finomítás jellemző, ez a mozgáskoordináció szakasza. Lassan létrejön a dinamikus sztereotípia, kialakulnak a reflexkapcsolatok. A mozgásszerkezetben rendezettség, harmónia jön létre.

A 4. szakasz a készséggé alakulás fázisa. A szenzomotoros egység és a feltételes reflexkapcsolatok összefüggő láncolattá fejlődnek. 
Az 5. szakasz a készség teljes kialakulásának fázisa. Ezt a fázist stabilizációs szakasznak is nevezzük. A mozgáscselekvések irányítása kérgi szintről gerincvelői szintre tevődik át. Az automatizálódott mozgás állandóan károsodhat, ezért meg kell követelni a tanítványoktól, hogy gyakoroljanak változó körülmények között is maximális erőfeszítéssel.

\section{A tánc tanításának módszertana}

A módszer szó görög megfelelője a methodosz, ami a nevelési műveletek sorrendjét jelenti, szűkebb értelemben: valamely helyzet megoldási módja. „A nevelési módszerek olyan eljárások, fogások vagy technikák, amelyek segítségével a pedagógus képes személyiségformáló feladatainak a megvalósítására" (Horváth, Palotay, 2000).

\section{A módszer megválasztósát meghatározó tényezők}

- Mi a nevelési cél?

- Mi a tanítás tartalma? Néptánc, divattánc, balett, társastánc stb., mind-mind különböző módszereket igényelnek.

- A tanulók életkora, fejlettségi foka: a terhelés mértéke olyan legyen, hogy a diákok szervezete azt jól viselje.

- A tanulók táncos előképzettsége: A 6-10 éves korosztály utánozva tanul, minimális a mozgástapasztalatuk. A későbbi korosztályoknál is fontos az utánzás a tánc lépéseinek elsajátításában, de itt már a magyarázat is fontos szerepet tölt be. Tudatosítani kell, hogy mi, miért történik, és hogy miért oda kell lépniük.

- Az oktató személyisége, pedagógiai kulturáltsága, lehetőségei.

Ismert, hogy más módszereket kell alkalmazni az új anyag elsajátításához, mást a gyakoroltatáshoz, és mindezeknek összefüggésben kell állniuk a képzettségi szintekkel is.

A föbb alkalmazott módszerek közé tartozik az ismeretközlés, a gyakoroltatás, hibajavítás és ellenőrzés (Fügedi, Bognár, Salvara, 2006).

\section{Ismeretközlés (szemléltetés, magyarázat)}

A módszerek alkalmazásai egymástól elválaszthatatlanok, de ha jól választjuk meg őket, segítik az oktatás-nevelés eredményességét, és elkerülhetjük a lépések helytelen elsajátításából fakadó rossz beidegződést.

Ahhoz, hogy a tanuló megfelelő mozgásképet alakítson ki magában, szükséges számára a szóbeli, vizuális és kinesztetikus információk egységes megléte. Minél több érzékszervet vonunk be a mozgástanulás folyamatába, annál könnyebben érthető és sajátítható el a táncos anyag. A táncnál a szemléltetés az egyik legfontosabb alkalmazott módszer, amely 
a magyarázattal szinte egybeesik. A vizuális információnyújtás indítja el a mozgáskép kialakulását, mely valós képet ad a mozgás tempójáról. A tanár szerepe fontos a tánclépések bemutatásánál, ezért a tanárnak ügyelnie kell mindig arra, hogy a bemutatás mindig mintaszerü, technikailag jól kivitelezett legyen a tanulók képzettségi fokának megfelelően. Ugyanakkor fontos, szemléletes is legyen, és a megfelelő síkból történjen az elsajátítandó táncmozdulat. Másképp tanítunk tükrös teremben, és másképp, ha nem használunk tükröt. Ebben az esetben, ha szemben állunk a tanulókkal, mindig tükörképet kell mutatnunk. Fontos, hogy a tanulók jól lássanak minket, és ne legyenek takarásban.

\section{Gyakoroltatás}

A lépések elsajátítása során szembesül a tanuló azzal, hogy a megtanulandó mozgás nehézségekkel jár. Ha már ezzel megbirkózott, akkor a mozgását tökéletesíteni kell, tehát gyakorolnia kell. A gyakorlás során fejlődik a mozgáskészség, fejlődik a fizikai képesség, alkalmazkodik a tanuló a változó körülményekhez. Törekednünk kell arra, hogy a gyakorlás tudatos legyen. Ehhez szükséges, hogy a tanár ismerje a lépések helyes technikai végrehajtását, a gyermek fizikumát, teherbíró képességét.

\section{Hibajavítás}

A mozgásoktatásban, így a társastáncban is elengedhetetlen a hibajavítás. Ha a gyakorlás során rossz reflexkapcsolat idegződik be, azt később sokkal nehezebb kijavítani, mint az új kapcsolatokat kialakítani. A táncban probléma lehet a mozgás szerkezetében és a technikai végrehajtásban. A hiba keletkezhet hiányos megértés, pontatlan lényegkiemelés, rossz bemutatás során, vagy ha nem a tanulók előképzettségének megfelelő lépésanyagot akarjunk megtanítani. Hibáznak a tanulók figyelmetlenség esetén, vagy ha rossz a mozgás beidegződése. Kezdetben még ezeken felül a görcsös mozgás, túlzott erőkifejtés okozhat problémát.

A hibajavítás leghatékonyabb módja az új magyarázat és új bemutatás.

A hibajavítás szempontjai:

- $\quad$ először mindig a lényeges hibát javítsuk ki, majd csak ezután történik a mozgás csiszolása,

- apró hibáknál ne szakítsuk meg a gyakorlást,

- az ügyetlen diákot ne pellengérezzük ki mások előtt,

- a fegyelmezetlenséget ne türjük meg,

- szoktassuk önellenőrzésre a tanítványokat! 


\section{Ellenőrzés}

Fontos része a tanítás-tanulás folyamatának az ellenőrzés, szorosan összefügg a hibajavítás módszerével. Ha elhanyagoljuk, akkor a tanulók is hajlamosak lesznek a munka elhanyagolására. Az ellenőrzés során győződik meg a tanuló arról, hogy hogyan fejlődött eddig a gyakorlás folyamán.

Ellenőrzés módszerei:

- a szóbeli megértést visszakérdezéssel ellenőrizhetjük,

- a lépések pontos kivitelezését a cselekvés folyamatában, azaz táncolás közben kontrollálhatjuk,

- és ennek mentén győződhetőhetünk meg a mozgás végrehajtásának eredményeiről.

\section{A tánc tanításának külső és belső feltételei}

\section{Külső feltételek}

Az elsők közé tartozik a megfelelő terem és burkolat. Nem szerencsés a régi nagy tornaterem, mert az visszhangzik, rideg, a burkolat nem rugalmas. A tánchoz az osztályterem csak akkor alkalmas, ha a padokat az óra előtt kipakoljuk a teremből, és felmossuk a padlót. Legmegfelelőbb hely egy nagy terem rugalmas burkolattal, amelyet a tánc tanításához alakítottak ki, és ahol állandó helye van a zenét biztosító technikai eszközöknek és az elmozdítható táblának. Szükséges az, hogy a terem jól szellőztethető legyen, és a padló mindig tiszta állapotban álljon a rendelkezésünkre. Ha a terem temperáltsága $18^{\circ} \mathrm{C}$ alatt van, tilos az órát megtartani. Legyenek öltözők, mosdóhelyiségek és WC-k a teremhez közel.

A másik fontos külső feltétel az öltözék. Minden táncstílushoz kifejlesztették a legmegfelelőbb cipőt. Még ha nem is követeljük meg a beszerzését, ügyeljünk arra, hogy az órán a tanulók ne jelenjenek meg utcai cipőben, bakancsban és papucsban. Követeljük meg a félcipő viselését. Ha a stílus megköveteli, a lányok táncruhában jelenjenek meg a foglalkozásokon.

A tánczene szintén lényeges külső feltétel, mert a társastánc a táncstílusoknak megfelelően megkomponált zenére történik. Hogy zenére táncolhassunk, a táncórák fontos feltétele a zenét lejátszó eszközökön kívül a megfelelő minőségű hanganyag biztosítása. 


\section{Belső feltételek}

Elsősorban a tanár maga tartozik ide. A tanár táncos felkészültsége elengedhetetlen, de önmagában kevés, ha a gyermek nem érzi a személyes törődést. A tanár legyen szigorú, de ugyanakkor megértő. Fontos, hogy szeresse a munkáját, mert csak ez által érheti el azt, hogy a tanítványai is megszeressék a táncot; tudjon motiválni és differenciáltan oktatni, a foglalkozásokat szakszerüen, szervezetten, gördülékenyen és jó hangulatban vezesse le. Fontos, hogy kapcsolatot tudjon kialakítani a szülőkkel és a tanulókkal, szerezzen a táncnak tekintélyt. Legyen türelmes, nyugodt, nehezen lehessen kihozni a sodrából, és ne zavarja, ha egy-egy lépést többször is el kell magyaráznia, és meg kell mutatnia a csoportnak, mire végre sikerül a gyerekeknek elsajátítaniuk a lépéskombinációkat. Meg kell tudnia oldani a mérhető célok és követelmények elsajátítását biztosító ismeretanyag és mozgásanyag elrendezését és tervezését.

A pedagógusnak a következő vezetői képességekkel kell rendelkeznie:

- Tudja biztosítani a mozgásanyag optimális felfogását és megértését, tudnia kell, hogy hova álljon a tanuló, hogy optimálisan érezze az elsajátítandó tánc lépéseit!

- A foglalkozásainak legyen megfelelő időbeosztása, gördülékenyen történjen az oktatás!

- Ki kell tudnia alakítani a tanítványokban az együttműködéshez szükséges belső feltételeket, mint pl. akarás, érzelem, érdeklődés, motiváció, figyelem, fegyelem!

- Mozgósítsa a tanítványok képzeletét és gondolkodását!

- Tudja irányítani a tanulók tevékenységét!

Az egyik legnagyobb bűn felelőtlenül tanítani. Belekapni az egyik, majd másik anyagba, félinformációkat adni, rosszul vagy sietve bemutatni a feladatot, vagy az, ha az órák rendszeresen elmaradnak, és nem szaktanár helyettesít. Ekkor a tanítvány kedve elmegy az egésztől, és a táncról csak rossz elképzelése lesz. Ha a módszertannal az oktató nincs tisztában, a helytelen tanítás maradandó károsodást okozhat (pl. nem megfelelően végzett bemelegítéssel sérüléseket okozhat, helytelen tartásbeli beidegződések gerincproblémákhoz, ízületi károsodásokhoz vezethetnek). Motiválni folyamatosan kell, nem válhat unalmassá, lapossá egy foglalkozás, ha egy nehéz figurakombinációt újra és újra gyakoroltatni kell. Az oktató attitűdje legyen pozitív, nyugodt, türelmes, rugalmas! Váljon példaképpé, mivel nemcsak a mozgását utánozhatják, hanem a viselkedését is, ami által észrevétlenül adja át az erkölcsi értékeket, a helyes viselkedési mintákat. Az a pedagógus, aki szereti és tudja a tantárgyát, amit oktat, az a tanulóival meg is tudja taníttatni, és ami még fontosabb: meg is tudja szerettetni azt.

Szeresd a táncot oktatni, és meglátod: a növendéked is meg fogja szeretni! Ez a legfontosabb cél. 


\section{Felhasznált szakirodalom}

Alex Moore (1985): Társastánc. Zenemű Kiadó, Budapest.

Báthory Béla (1981): A testnevelés elmélete és módszertana I. Kézirat, Tankönyvkiadó Budapest.

Báthory Béla, Aradi László, Makszin Imre, Nádori László: A testnevelés elmélete és módszertana. TF tankönyv Sport, Budapest.

Berczik Sára (1992): Mozgásfejlesztő és tartásjavító gimnasztika. Iskolai testnevelési és sportfüzetek. Művelődési és Közoktatási Minisztérium, Budapest.

Bognár József, Tóth Láaszló, Baumgartner Eszter, Salvara I Marina (2005): Tanulás, célok és testnevelés: Előtanulmány az általános iskola felől. In: Mónus, András (szerk.) 4. Országos Sporttudományi Kongresszus. 1-2. kötet : A sporttudomány és az európai integráció - globális és lokális összefüggések. Iskolai testnevelés, utánpótlás-nevelés, tehetséggondozás. Budapest, Magyarország : Magyar Sporttudományi Társaság, 29-34.

Bognár József, Tóth László, Baumgartner Eszter (2003): Gondolatok a tanulásról. Iskolai Testnevelés és Sport, 14-17.

Fark Horváth László, Palotay Ferencné (2000): Neveléstan. Besenyei György Könyvkiadó, Nyíregyháza.

Fügedi Balázs, Bognár József, Salvara I. Marina (2006): A mozgástanulás tervezése: 5-8. osztályos tanulók és testnevelőik tapasztalata. ACTA ACADEMIAE PAEDAGOGICAE AGRIENSIS NOVA SERIES: SECTIO SPORT, 33, 47-64.

Kokas Klára (1980): Gyermekek zenei kifejezési formáiról. Élet és Tudomány, 1. SZ.

Láng Éva (2005): A latin-amerikai táncok története és a jive lépés anyaga szakdolgozat, Eger.

Nagy Sándor (1967): Didaktika. Tankönyvkiadó, Budapest.

Poszler György (szerk.) (1980): Az esztétikai nevelésről. Kossuth Könyvkiadó, Budapest.

Rátkai István (2000): Testnevelés tantárgypedagógia. Nemzeti Tankönyvkiadó, Budapest.

Réthy Endréné (1988): A tanítás-tanulási folyamat motivációs lehetőségeinek elemzése. Akadémiai Kiadó, Budapest.

Stuller Gyula (2001): Lélektan. Előadásvázlatok Fitness Kft. Budapest.

Új magyar lexikon (1962) 5. kötet 188.old. Akadémiai Kiadó. Budapest. 